Morskoy spetsialist segodnya: svyaz lichnostnykh kachestv s usloviyami raboty [Marine specialist today: connection of personal qualities with working conditions]. Science and modernity. Vol.1(7), pp.149-157. Available at: http://ucom.ru/doc/ns.2016.01.pdf. [in Russian].

11. Sokol, I.V. (2011). Formuvannia profesiinoi kompetentnosti maibutnikh sudnovodiiv u protsesi vyvchennia fakhovykh dystsyplin [Future navigators professional competence formation in the process of special disciplines study]. Extended abstract of candidate's thesis. Kherson State University, Kherson, 20 p. [in Ukrainian].
12. Fadeyeva, V.V. (2001). Formirovaniye informatsionno-kompyuternoy gotovnosti budushchikh voyenno-morskikh spetsialistov [Formation of information and computer readiness of future naval specialists]. Candidate's thesis. Kaliningrad State University, Kaliningrad. [in Russian].

13. Tsibulskaya, E.V. (2001). Teoriya i metody professionalnogo yazykovogo obrazovaniya morskikh sudovoditeley [Theory and methods of professional language education of marine navigators]. Doctor's thesis. Siberian State University of Water Transport, Novosibirsk. [in Russian].

Стаття надійшла до редакції 20.05.2019

УДК 780.616.432:784.3

DOI:

Світлана Мудра, старший викладач кафедри музикознавства та фортепіано Інституту музичного мистеитва Дрогобиџького державного педагогічного університету імені Івана Франка

\title{
ФОРТЕПІАННИЙ РОМАНС: ОСОБЛИВОСТІ ЖАНРОВОЇ СТИЛІСТИКИ
}

У статті розглядаються фортепіанні романси українських композиторів (М. Калачевського, М. Лисенка, М. Ластовецького) і оглядово російських, яких є значно більше. Вказано на пісенно-побутове коріння жанру, який належить до ліричних. Звідси випливає загальна тенденція домінування наспівності як основного чинника образної семантики. Проаналізовані зразки свідчать про використання композиторами XIX - ХХ століть деяких типових виражальних засобів і прийомів, а також про індивідуальні художньоестетичні трактування спільного романсового підтрунтя.

Ключові слова: романс; фортепіанний твір; композитор; пісенність; жанр.

Jim. 7.

Svitlana Mudra, Senior lecturer of the Musicology and Piano Department Institute of Music Art Drohobych Ivan Franko State Pedagogical University

\section{PIANO ROMANCE: FEATURES OFTHE GENRE STYLISTICS}

In the studies of Ukrainian scholars about the piano music the special attention to the genre of piano romance was not drawn. Therefore, the article attempts to investigate the figurative and stylistic features of this genre in the piano creativity of Ukrainian composers.

The genre fund of the Ukrainian piano music is rich and diverse. Lyrical instrumental genres occupy an outstanding place in it. Piano romance is similar to piano song, which is widely represented in works of the Ukrainian composers of different generations. A song was mentally closer to them. It is noted that the vocal romance, which originates from the author's song of the urban tradition, differed in certain stylistic peculiarities, which were partly transferred to a piano piece. The article deals with the pieces named "Romance" written by Russian and Ukrainian composers of the second part of the nineteenth century to our time. It has been mentioned that piano romances were more characteristic of the representatives of the Russian national school and the Ukrainian composers from Naddnipryanshchyna. The Galician composers didn't pay much attention to this genre; Ukrainian folk songs in piano arrangement prevailed in their work.

The analyzed piano romances composed by the Ukrainian authors are the examples of romantic (M. Kalachevskiy, M. Lysenko) and neo-romantic (M. Lastovetskiy) national styles and the corresponding figurativeemotional circle. The main peculiarities of the genre stylistics of these works are: sincerity of feelings, exaggerated expression and some sentimentality at the same time. Singing is combined with narration, or recitative. For the development of musical material such techniques as sequencing, the presence of several climaxes, harmonic-texture variation, agogic nuances, three-part form, sometimes with contrasting parity of parts are typically used. Thanks to these piano romances are often performed in concert programs; they are popular in the educational repertoire.

Keywords: romance; piano composition; a composer; a song; a genre.

П остановка проблеми. Впродовж історії розвитку української фортепіанної музики сформувалися суго інструментальні й лірико-пісенні жанри. Серед останніх вирізняються: 1) такі, що походять від фольклору, 2) "міської генези”. Як відомо, жанр фортепіанної пісні має 


\section{ФОРТЕПАННИЙ РОМАНС: ОСОБЛИВОСТІЖАНРОВОЇ СТИЛІТИКИ}

двояке коріння - народне й індивідуальноавторське. Натомість фортепіанний романс бере початок від перекладень авторських вокальнокамерних композицій, переважно зі сфери міського побуту. Перші зразки “пісень” і “романсів" для фортепіано знаходяться в збірках транскрипцій Миколи Маркевича, Алоїза Сдлічки та інших.

Аналіз останніх досліджень і публікацій. Якщо українська вокально-романсова творчість вивчалася багатьма дослідниками (Микола Грінченко, Онисія Шреєр-Ткаченко, Богдана Фільц, Роман Сов'як, Тамара Булат, Оксана Басса та інші), то про інструментальний романс (в тому числі, фортепіанний) цього сказати не можна. В праці Віктора Клина "Українська радянська фортепіанна музика" подано розгалужену систему жанрового фонду названої галузі творчості за такими видами, як прості жанри (пісня, танець, марш) [3, 9], жанри лірики та епосу (елегія, серенада, “роздуми”, “мрії”, баркарола, речитатив, ноктюрн, поема; балада, легенда, рапсодія, фантазія на народну тему, казка, дума, новела, новелета) [3, 39], моторні жанри (танець, марш, етюд, токата, скерцо, гумореска, бурлеска) $[3,81]$, жанри додаткової класифікації (прелюдія, інтермецо, постлюдія; експромт, музичний момент, ескіз, імпровізація, експресія; фантазія, каприччіо; канон, інвенція, фуга, прелюдія та фуга) [3, 145], синтетичні жанри (сюїта, варіації, соната) [3, 234]. Та фортепіанний романс, який доречно було би трактувати як один iз ліричних жанрів, не знайшов тут висвітлення. В дослідженнях українських науковців про фортепіанну музику окремих композиторів на жанр романсу спеціальна увага не зверталася. Цим зумовлюється актуальність теми.

Мета статті полягає у з'ясуванні художньообразних і стилістичних особливостей жанру романсу у фортепіанній творчості українських композиторів.

Виклад основного матеріалу дослідження. Дослідники історії української музичної культури відзначили, що зародження й формування пісніромансу відбувалося з останніх десятиліть XVIII століття. Для неї була типовою романтична тематика поетичної основи: любовні переживання, тужливі й меланхолійні настрої. Особливістю пісні-романсу названа виразна мелодика, якою виражалися інтимно-суб'єктивні почуття [5, 177]. “Розвиток цього жанру”, - як зазначила О. ШреєрТкаченко, - “пов’язаний з українською поезією. На початку XIX століття пісні-романси склададися на тексти маловідомих авторів. У них звучав сумний роздум над долею людини, фоном для відтворення переживань людських часто був ліричний або романтичний пейзаж. Іноді лірика зітхання перетворювалася на пристрасне поривання до щастя й волі $[7,142]$. Т. Булат окреслила такі прийоми мелодичної побудови української пісні-романсу, як “мінорний лад, м'які, навіть інколи з підкресленою чуттєвістю інтонації” $[1,275]$. Ці прикмети відповідно відобразилися й на фортепіанних романсах, що з'явилися в XIX столітті. Та варто зауважити про поширення таких п’єс в російській композиторській школі.

"Романс" тв. 44 № 1 Антона Рубінштейна одне $з$ перших звернень до цього жанру. У цьому двочастинному творі основне виразове навантаження несе права рука, в лівій зосереджений акомпанемент до експресивної провідної теми та інших мелодичних побудов (за винятком двох тактів наприкінці романсу, де в партії лівої руки проводяться два мелодизовані звороти). Характерною рисою мелодії твору є секвенційний розвиток, у якому важливу роль відіграють хроматичні оспівування тонів. У другій частині пришвидшується темп і з'являються похідні мотиви із закличними інтонаціями. Автор вдався тут до їхніх тембрально-регістрових “перезабарвлень".

"Романс" тв. 15 № 2 Миколи РимськогоКорсакова - невеликий монотематичний твір. Його тема-мелодія неспішно й задумливо розгортається в секвенційному русі - спочатку у “віолончельному” регістрі з переходами з однієі партії до іншої, потім переноситься на октаву вище. Тема, оповита супровідними голосами в тісному розташуванні й синкованій ритміці, виражає глибоку задуму через постійні повторення тих самих мотивів, що урізноманітнюються їхнім гармонічним оформленням.

“Романс" тв. 53 № 3 Антона Аренського написаний у тричастинній формі. Для його крайніх частин властиве насичення мелодичної лінії речитативними фразами, для жвавішої серединної побудови - пощаблевий рух нової теми та їі розгортання за допомогою секвенційних ланок. Саме при переході до репризи відбувається кульмінаційний момент - короткочасний, але доволі бурхливий, позначений інтенсивними гармонічними відхиленнями. Супровід романсу однотипний, витриманий утріольному викладі.

“Романс" тв. 10 № 6 Сергія Рахманінова сугтєво відрізняється за образним строєм від п’єс його попередників. Його мелодика сумна (doloroso), наповнена зітхальними й запитальними інтонаціями та тужливими зворотами-унісонами в речитативно-декламаційній манері. Тому твір швидше нагадує оперну арію у 
двох частинах із інструментальним вступом, аніж пісню-романс. Кульмінація акордова, з деяким відтінком трагізму. Домінуючий образноемоційний склад доповнений вживанням пониженого другого щабля в мінорі (похмурий фрігійський лад).

Дмитро Шостакович вирішив свій "Романс" у спокійно-світлому образному ключі, наближеному до пасторалі чи баркароли (розмір 6/8). У кожній 3 двох частин мелодико-гармонічний розвиток приводить до кульмінаційної вершини, що, однак, позбавлена патетики. Музика сприймається як розповідь про поривання до мрії. Фактура твору гомофонно-гармонічна, прозора.

Подібно до Д. Шостаковича, Борис Чайковський показав у "Романсі" відхід від романтичних традицій, максимальне спрощення виражальних засобів. Лаконічна п’єса написана у наскрізній формі. Плинна мелодія розповідного типу розгортається без пауз, без повторів, прямуючи до скромної кульмінації на $m f$ перед закінченням.

В українських композиторів інтерес до жанру фортепіанного романсу помітно менший. Це можна пояснити домінуванням автентичних фольклорних джерел у їх творчому переосмисленні або цитатному використанні. 3 іншого боку, російська музична культура мала значний вплив на формування української музики в XIX столітті у зв' язку з суспільно-історичними обставинами. Можливо тому створення романсів для фортепіано обмежується представниками Наддніпрянщини - Миколою Калачевським (Колачевським) і Миколою Лисенком. У спадщині галицьких композиторів фортепіанних романсів немає, в цьому регіоні більш популярним був жанр елегії, який бере початок із старогалицької авторської пісні-елегії.

Творча спадщина М. Калачевського невелика. Як і М. Лисенко, він навчався у Ляйпцизькій консерваторії. Серед кількох його фортепіанних творів, яким у цілому “притаманна поетична задушевність”, за Лідією Корній [4, 247], міститься "Романс". Він викликає паралелі до традиційного для XIX століття домашнього музикування, одним із видів якого був спів 3 гітарним акомпанементом. Підтвердженням цього є насамперед структура твору: вступ і закінчення засновані на арпеджованих акордах, чим імітується гітарне звучання.

Проникливий мелос п’єси концентрує палітру різноманітних емоційних відтінків. Шляхетний вираз глибокого почуття в крайніх частинах (Tranquillo, ma con espressivo) змінюється трепетним неспокоєм середини (Piu mosso). Поступове посилення хвилювання тут відбувається з несміливого й тихого одноголосого мотиву, на який нашаровуються інші голоси, зливаючись уакордовій фактурі та наповнюючись хроматизацією. Дві динамічно-фактурні хвилі (перша в паралельному мінорі, друга в тональності третього щабля) завершуються кульмінаційним згущенням експресії, за яким слідує затихання й перехід до скороченої репризи.

Якщо для першої частини були характерні випуклі речитативні звороти-вставки, то в репризі вони відсутні, натомість панує суцільна наскрізна драматизація. Тому кульмінаційний момент розвитку тут яскравіший, ніж на початку твору. Таким чином, для цього романсу властиві три досить стрімкі фази наростання в короткому часі тривання, що надає йому сентиментального нахилу.

“Романс" ор. 27 М. Лисенка був написаний упродовж 1885 - 1886 років, тобто, ще до його навчання в Лейпцігській консерваторії. Не дивлячись на те, що це один із ранніх творів, у нотному тексті помітний почерк зрілого майстра. Це й не дивно - адже Лисенко на той час вже був сформованим піаністом, із значним концертним досвідом і репертуарним запасом.

Як і у своїх обробках народних пісень, композитор у цій п’ $є$ сі запровадив короткий вступ до появи теми cantabile. Басово-гармонічні опори вступу грунтуються на тонічному органному пункті, потім на чергуванні тоніки й домінанти, в той час як акорди правої руки охоплюють, крім цих основних функцій, також і шостий щабель. Це надає вступові своєрідного гармонічного колориту. Тут закладено коливальний мотив і в останньому такті синкопу, яка надалі стає прикметною ознакою супроводу мелодії.

Експозиційний виклад матеріалу- гомофонногармонічний. Вся фактура підпорядковується наспівній і стриманій темі (4+5), яка звучить тихо, але поступово підіймається догори й відразу, з другої фрази, отримує ремарку espress. Для початкових двотактових тематичних мотивів властиве пропущення першої вісімкової частки. Ця якість особливо увиразнюється у другій фразі, де такий вигляд має кожний такт, унаслідок чого й з'являється посилена експресивність вислову. Вона підкріплюється композитором ще й артикуляцією - позначеннями акцентів і маркато. Відбувається відхилення в паралельний мінор i, перед поверненням до основної тональності, агогічна зміна (rubato).

Наступне проведення теми показове інтонаційною трансформацією другого речення, що розширюється до шести тактів. Новий короткочасний підйом на форте спадає, спокійно 


\section{ФОРТЕПАННИЙРОМАНС: ОСОБЛИВОСТІЖАНРОВОЇ СТИЛІСТИКИ}

завершуючи з дімінуендо першу частину романсу.

В середині початковий темп Andante sostenuto змінюється росо ріu mosso, тональність на домінантову. Нова тема не надто відрізняється вона так само наспівна, в іiї інтонаційному складі подібні мотиви з пропущеною першою вісімкою, присугня синкопа в партії лівої руки. Та все ж $\epsilon$ фактурні відмінності: гомофонний виклад поступається насиченню теми поліфонічними елементами. Спершу це неточні імітації мелодичних уривків у середньому голосі, потім приховане чотириголосся. Завдяки цьому досягається більша схвильованість почуттів (animando), їхній розвиток, а наприкінці середини - черговий спад динаміки й темпу.

Зате динамізована реприза твору зі свого першого такту демонструє значний емоційний накал, якому сприяють октавний вигляд основної теми та тріольно-акордовий супровід у поліритмії; подекуди вклинюється синкопований ритмічний малюнок. Частина тематичного матеріалу поміщена у високі регістри. При підході до генеральної кульмінації романсу ( $f f$, molto passionato) й впродовж iї тривання в мелодії значно урізноманітнюються ритміка та ладогармонічний план. Незначне затихання призводить до останнього емоційного підйому (con agitatione, $f$ ), після чого на кадансі все стишується.

Кінцівка побудована на тонічному органному пункті та вступних функційних акордах, які тепер рухаються вгору, поступово затихаючи до піанісімо. “Романс” Лисенка слугує прикладом до тези Наталії Кашкадамової про те, що основним характером звучання його фортепіанної фактури $€$ пісенність, “відчутна при кожному складі гомофонному, поліфонічному чи акордовому” [2, 488]. Для доповнення характеристики його "Романсу" також цілком придатне зауваження Л. Корній про “полімелодизацію фактури” композитора [4, 444].

В сучасній українській фортепіанній творчості до жанру романсу звернувся Микола Ластовецький. Його “Театральний романс" із I зошита фортепіанних п'єс для дітей і юнацтва показує трактування жанру сучасним композитором.

3 цього огляду показовою $є$ його ремарка до твору - Andante romantico, що націлює на особливий спосіб виконання. Тричастинна композиція побудована в традиційному для жанру плані: спокійним крайнім частинам у мажорній тональності протиставляється рухливіша середня, 3 новим тематизмом у мінорній тональності третього щабля. Мелодика тотожних експозиції репризи позначена розповідним тоном. Їй притаманний двоголосий виклад (спочатку паралелізмами секст, а потім низхідні секвенції на тлі витриманих звуків середнього голосу). Акомпанемент являє собою розкладені співзвуччя.

Нова мелодія відзначається схвильованістю коротких мотивів, які переходять у речення із щоразу дрібнішим поділом часток такту. Секвенційне рогортання набуває експресивнодраматичних рис у кульмінаційному фортісімо. Важливу роль у цьому відіграють гармонічні переходи. Але це не єдиний емоційний сплеск. Після наступної низки секвенцій з'являється підкреслено декламаційний і гучний зворот із паралельних секст $(f f)$, після якого сповільнюється темп і настає затихання звуку. О. Фрайт зауважила в цій п’єсі індивідуальні уподобання композитора, який плідно працює в галузі створення музики до театральних вистав: “у цьому "романсі” наче віддзеркалюється узагальнена концепція більшості сценічних драматичних творів. Наповнена хвилюванням почуттів середина, кульмінацією якої $\epsilon$ пристрасний порив, обрамлюється “прологом” і “епілогом” - зав'язкою і розв'язкою дії, на ідентичному матеріалі, де переважає розповідносентиментальна атмосфера" [6, 78].

Висновки. Таким чином, проаналізовані фортепіанні романси українських композиторів $\epsilon$ зразками романтичного(М.Калачевський, М. Лисенко) i неоромантичного (M. Ластовецький) національних стилів і відповідного образноемоційного кола. Особливостями жанрової стилістики цих творів є відвертість почуттів, іноді перебільшена експресія вислову і разом з тим деяка сентиментальність. Співучість поєднується 3 розповідністю, інколи - 3 речитативністю. Для розвитку музичного матеріалу властиві такі прийоми, як секвенційність, наявність кількох кульмінацій, гармонічно-фактурне варіювання, агогічні нюанси. Домінує тричастинна форма, іноді 3 контрастними зіставленнями частин. Такими фортепіанними засобами українські композитори передали інтонаційно-образні особливості романсової сфери. Завдяки цим засобам фортепіанні романси часто виконуються в концертних програмах, вони є популярні в навчальному репертуарі.

\section{ЛІТЕРАТУРА}

1. Булат Т. П. Обробки українських пісень для голосу в супроводі фортепіано /М. М. Гордійчук (голова), Т. П. Булат, С. Й. Грица та ін. Історія украӥнської музики в шести томах. Київ, 1989. Т. 1. С. 38-76. 
2. Кашкадамова Н. Б. Історія фортеп'янного мистецтва XIX сторіччя : підручник. Тернопіль, 2006. 608 с.

3. Клин В. Українська радянська фортепіанна музика. Київ, 1980.316 с.

4. Корній Л. П. Історія української музики. Частина третя. (XIX ст.) : підручник. Київ - Нью-Йорк, 2001. 479 с.

5. Корній Л., Сюта Б. Українська музична культура. Погляд крізь віки. Київ, 2014. 592 с.

6. Фрайт О. Фортепіанні альбоми та цикли українських композиторів для дітей: історія і сучасність: навчально-методичний посібник. Дрогобич. 100 с.

7. Шреєр-Ткаченко О. Л. Історія української музики. Частина перша : Розвиток української музичної культури від найдавніших часів до середини XIX століття. Київ, 1980. 198 с.

\section{REFERENCES}

1. Bulat,T. P. (1989). Obrobky ukrainskykh pisen dlia holosu v suprovodi fortepiano [Processing of Ukrainian songs for voice accompanied by piano]. History of Ukrainian music in six volumes. Kyiv, Vol. 1, pp. 38-76. [in Ukrainian].
2. Kashkadamova, N. B. (2006). Istoriia fortepiannoho mystetstva XIX storichchia : pidruchnyk. [The history of piano art. XIX century: textbook]. Ternopil, 608 p. [in Ukrainian].

3. Klyn, V. (1980). Ukrainska radianska fortepianna muzyka [Ukrainian Soviet Piano Music]. Kyiv, 316 p. [in Ukrainian].

4. Kornii L. P. (2001). Istoriia ukrainskoi muzyky. Chastyna tretia. (XIX st.) : pidruchnyk. [The history of Ukrainian music. p. 3 (XIX century): textbook]. Kyiv Niu-York, 480 p. [in Ukrainian].

5. Kornii, L. \& Siuta, B. (2014). Ukrainska muzyczna kultura. Pohliad kriz viky [Ukrainian music culture. A look throught heages]. Kyiv, 592 p. [in Ukrainian].

6. Frait, O. (2013). Fortepianni albomy ta tsykly ukrainskykh kompozytoriv dlia ditei: istoriia i suchasnist [Piano albums and cycles of Ukrainian composers for children: history and modern times]. Drohobych, $100 \mathrm{p}$. [in Ukrainian].

7. Shreier-Tkachenko, O. L. (1980). Istoriia ukrainskoi muzyky. Chastyna persha [The history of Ukrainian music]. Kyiv, 198 p. [in Ukrainian].

Стаття надійшла до редакції 23.05.2019

УДК 373.3/.5].014(410+477)

DOI:

Галина Лотфі Гаруді, викладач кафедри іноземної мови Національного університету “Львівська політехніка"

\section{ПОЛІТИКА УПРАВЛІННЯ ОСВІТОЮ УКРАЇНИ ТА ВЕЛИКОЇ БРИТАНІЇ}

У статті висвітлено головні напрямки реформи у галузі загальної середньоі освіти України та Великоі Британії. Зокрема, йдеться про перегляд національного курикулуму, удосконалення освітної системи відповідно до світових стандартів. Показано зміни в освіті та ї̈ реформуванні. Виокремлено механізми впровадження основних європейських норм і стандартів у формуванні сучасного вектора розвитку національної освіти та виявлено завдання свідомо регульованого удосконалення шкільної освіти. Проаналізовано курс програм освітніх систем. Доведено ефективність впровадження нововедень, а саме “модуль” як навчальний пакет.

Ключові слова: реформа; навчальний курикулум; освітя система; модульне навчання; стандарти досягнень; загальне свідочттво про середню освіту.

Лim. 12.

Halyna Lotfi Ghahrodi, Lecturer of the Foreign Languages Department National University "Lviv Polytechnic"

\section{EDUCATIONAL MANAGEMENT POLICY OF UKRAINE AND GREAT BRITAIN}

This article highlights the main direct reforms of secondary education in Ukraine and Great Britain. In particular, it is about the revision of the national curriculum, improvement of the educational system in accordance with the world's standards. Paper shows changes in education and its reforms. The mechanisms of implementation of the basic European norms and standards in the formation of the modern vector of development of national education are identified and the problem of knowingly regulated improvement of school education is revealed. The course of programs of educational systems is analyzed here. Education is the only sphere where a society adjusts its needs. English educational traditions are characterized by the persistence of traditions, differing in their organization, content and prospects. The British government is not willing to change in their educational system, although it believes that they should be up-to-date, should fulfill the function of spiritual formation of both man and mankind in general, not to make a breakthrough in achieving spiritual and intellectual progress of educational policy. The state of affairs in the school education system of Great Britain in recent years is clear evidence of great achievements in this area. The equilibrium of the quantity and quality of education is dictated by the new, diverse, growing 